\title{
Effects of Long-Term Treatment with Estradiol and Estrogen Receptor Subtype Agonists on Serotonergic Function in Ovariectomized Rats
}

\author{
Saloua Benmansour ${ }^{a}$ Opeyemi S. Adeniji ${ }^{a}$ Anthony A. Privratsky ${ }^{a}$ \\ Alan Frazer ${ }^{a, b}$

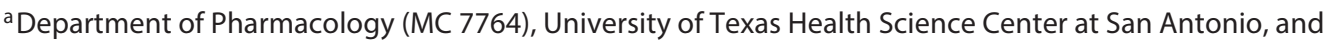 \\ ${ }^{b}$ South Texas Veterans Health Care System, San Antonio, Tex., USA
}

\section{Key Words}

Estradiol · Estrogen receptor agonists · Antidepressant .

Forced swim test $\cdot$ Signaling pathways

\begin{abstract}
Acute estradiol treatment was reported to slow the clearance of serotonin via activation of estrogen receptors (ER) $\beta$ and/or GPR30 and to block the ability of a selective serotonin reuptake inhibitor (SSRI) to slow serotonin clearance via activation of ERa. In this study, the behavioral consequences of longer-term treatments with estradiol or ER subtype-selective agonists and/or an SSRI were examined in the forced swim test (FST). Ovariectomized rats were administered the following for 2 weeks: estradiol, ER $\beta$ agonist (diarylpropionitrile, DPN), GPR30 agonist (G1), ERa agonist (PPT), and/or the SSRI sertraline. Similar to sertraline, longer-term treatment with estradiol, DPN or G1 induced an antidepressantlike effect. By contrast, PPT did not, even though it blocked the antidepressant-like effect of sertraline. Uterus weights, used as a peripheral measure of estrogenic activity, were increased by estradiol and PPT but not DPN or G1 treatment. A second part of this study investigated, using Western blot analyses in homogenates from hippocampus, whether these behavioral effects are accompanied by changes in the acti-
\end{abstract}

vation of specific signaling pathways and/or TrkB. Estradiol and G1 increased phosphorylation of Akt, ERK and TrkB. These effects were similar to those obtained after treatment with sertraline. Treatment with DPN increased phosphorylation of ERK and TrkB, but it did not alter that of Akt. Treatment with PPT increased phosphorylation of Akt and ERK without altering that of TrkB. In conclusion, activation of at least TrkB and possibly ERK may be involved in the antidepressant-like effect of estradiol, ER $\beta$ and GPR30 agonists whereas Akt activation may not be necessary.

๑) 2015 S. Karger AG, Basel

\section{Introduction}

Many of the effects of estrogen are mediated by estrogen receptors (ERs), primarily by ER $\alpha$ and ER $\beta$, which are encoded by different genes $[1,2]$. These receptors are regionally distributed throughout the body and brain [3]. Some of the regional differences in ER $\alpha$ versus ER $\beta$ distribution in brain may confer specific functional effects of estradiol $\left(E_{2}\right)$ acting via these receptor isoforms. ERa is predominant in the ventromedial hypothalamus and is related to the facilitatory actions of $E_{2}$ on female rodent sexual responding. ER $\beta$ is predominant in limbic and/or

\section{KARGER}

E-Mail karger@karger.com

www.karger.com/nen
(C) 2015 S. Karger AG, Basel

0028-3835/15/1034-0269\$39.50/0
Dr. Saloua Benmansour

Department of Pharmacology (MC 7764), University of Texas Health Science Center at San Antonio, 7703 Floyd Curl Drive San Antonio, TX 78229-3900 (USA)

E-Mail benmansour@uthscsa.edu 
stress-responsive regions of brain, such as the hippocampus, and is related to the affective behaviors of $\mathrm{E}_{2}$ [4]. The effects of $E_{2}$ in producing anxiolytic-like or antidepressant (AD)-like behaviors through activation of the ER $\beta$ subtype have been demonstrated using both ER $\beta$ knockdown and ER $\beta$ activation approaches [5-10]. Estrogen can act either by a genomic mechanism, using classical nuclear transcription factor receptors [11] or by a nongenomic, less well-characterized membrane receptor signaling mechanism [12]. The genomic pathway requires at least $30-60 \mathrm{~min}$ to be manifest and is associated with changes in protein synthesis. Rapid effects of estrogen occurring within seconds to minutes may be mediated by membrane receptors leading to activation of signaling pathways. $\mathrm{E}_{2}$ has both rapid as well as slower effects on serotonin transporter (SERT) function, indicating the involvement of nongenomic as well as genomic mechanisms in its effects $[10,13]$.

Recently, a novel G protein-coupled ER, GPR30 (also known as GPER1), has been identified [14]. GPR30 is a seven-transmembrane-spanning G-protein-coupled receptor that shows specific high affinity binding for $E_{2}$ and related estrogens and promotes rapid estrogen signaling in a variety of cell types [15]. The GPR30-specific agonist, G1, can reproduce many effects of estrogen [14]. In addition, acute activation of GPR30 by G1 mimicked the ADlike effects of $E_{2}$, similar to that observed with an ER $\beta$ agonist [10].

Using in vivo chronoamperometry in young adult ovariectomized (OVX) rats, acute systemic treatment as well as local administration of $\mathrm{E}_{2}$ produced changes in SERT function, as shown by a decreased basal clearance of serotonin (5-HT); it also prevented the inhibitory effect of the selective serotonin reuptake inhibitor (SSRI) fluvoxamine on 5-HT clearance [13]. These two effects were mediated by different ER subtypes: the AD-like effect of $E_{2}$ was due to ER $\beta$ and/or GPR30 activation whereas its blockade of the ability of an SSRI to slow 5-HT clearance was mediated by activation of ERa [10].

Two major signaling pathways have been associated with the effects of $E_{2}$ in the brain: mitogen-activated protein kinase (MAPK)/extracellular signal-regulated kinase (ERK1/2) and phosphatidylinositol-3-kinase (PI3K)/Akt (also known as protein kinase B) pathways. The mechanisms of $\mathrm{E}_{2}$ signaling in the brain are complex, tissue specific and include independent as well as codependent effects through ER $\alpha, E R \beta$ and GPR30 as well as interactions between ER and other membrane receptors such as insulin-like growth factor receptor (IGF-IR), metabotropic glutamate receptor (mGluR) and the neu- rotrophin (BDNF and/or NT3) receptor, TrkB [16-19]. In a recent study, it was shown that the acute effects of $E_{2}$ on SERT function are mediated by different as well as common signaling pathways. $\mathrm{E}_{2^{-}}$or diarylpropionitrile (DPN)-induced slowing of 5-HT clearance mediated by ER $\beta$ was blocked after inhibition of MAPK/ERK1/2 but not that of PI3K/Akt signaling pathways. $\mathrm{E}_{2}$ 's or PPT's inhibition of the fluvoxamine-induced slowing of 5-HT clearance mediated by ERa was blocked after inhibition of either MAPK/ERK1/2 or PI3K/Akt signaling pathways [19]. In addition, estrogen and BDNF seem to share common targets, effects and mechanisms of action [20]. Further, there is evidence for the neurotrophin TrkB receptor being a mediator of the effects of $\mathrm{E}_{2}$ in the hippocampus [21]. Consistent with this, the blockade of the TrkB receptor abolished the acute effect of $E_{2}$ and DPN on 5-HT clearance but had no effect on $\mathrm{E}_{2}$ 's or PPT's inhibition of the fluvoxamine-induced slowing of 5-HT clearance [19].

The brain's serotonergic system is complex, in part due to the diffuse distribution of its multiple receptor subtypes and the various signal transduction pathways regulated by these receptors [22]. Modulation of 5-HT neurotransmission has long been a primary pharmacological target for the treatment of depression and more recently anxiety disorders. SSRIs enhance synaptic 5-HT action by blocking the reuptake of 5-HT [23]. Global enhancement of 5-HT neurotransmission may activate all subtypes of 5-HT receptors in brain, whereas each 5 -HT receptor subtype has different and specific functions in defined brain regions $[24,25]$. Similar to the signaling of $\mathrm{E}_{2}$, two major signaling pathways have been implicated in responses underlying $\mathrm{AD}$ effects: the PI3K/Akt/glycogen synthase kinase-3 (GSK3) signaling pathway and the MAPK/ERK signaling pathway [24, 26]. In addition to its interaction with estrogen, BDNF and its $\operatorname{TrkB}$ receptor are also involved in the mechanism(s) of action of ADs [27]. Phosphorylation of the TrkB catalytic domain (tyrosine residue Y705) is considered to be the initial step in $\operatorname{TrkB}$ receptor activation, which further regulates the phosphorylation and activation of other tyrosines, of which Y515 (the docking site of the Shc adaptor protein) and Y816 have been most extensively studied [28]. AD treatment increased TrkB phosphorylation at Y705 as well as at Y816 but not at Y515 [29-31].

Previous studies primarily examined the acute effects of $E_{2}$ or subtype-selective agonists. However, $E_{2}$ is often given chronically, particularly for adjunctive treatment of postmenopausal depressed patients $[32,33]$. Therefore, 
Table 1. Treatment with PPT and/or sertraline

\begin{tabular}{lllllll}
\hline & Groups & & & \\
\cline { 2 - 6 } & control & PPT $(5 \mu \mathrm{g})$ & PPT $(50 \mu \mathrm{g})$ & sertraline & $\begin{array}{l}\text { PPT }(5 \mu \mathrm{g}) / \\
\text { sertraline }\end{array}$ & $\begin{array}{l}\text { PPT }(50 \mu \mathrm{g}) / \\
\text { sertraline }\end{array}$ \\
\hline $\begin{array}{l}\text { Osmotic minipump 1 } \\
\text { Osmotic minipump 2 }\end{array}$ & $\begin{array}{l}\text { vehicle } \\
\text { vehicle }\end{array}$ & $\begin{array}{l}\text { PPT }(5 \mu \mathrm{g}) \\
\text { vehicle }\end{array}$ & $\begin{array}{l}\text { PPT }(50 \mu \mathrm{g}) \\
\text { vehicle }\end{array}$ & $\begin{array}{l}\text { vehicle } \\
\text { sertraline }\end{array}$ & $\begin{array}{l}\text { PPT }(5 \mu \mathrm{g}) \\
\text { sertraline }\end{array}$ & $\begin{array}{l}\text { PPT }(50 \mu \mathrm{g}) \\
\text { sertraline }\end{array}$ \\
\hline
\end{tabular}

Table 2. Treatment with $E_{2}$, ER subtype-selective agonists and/or sertraline

\begin{tabular}{|c|c|c|c|c|c|c|c|}
\hline & \multicolumn{7}{|l|}{ Groups } \\
\hline & control & $\mathrm{E}_{2}$ & DPN & PPT & $\mathrm{PPT} /$ sertraline & sertraline & G1 \\
\hline $\begin{array}{l}\text { Osmotic minipump } 1 \\
\text { Osmotic minipump } 2\end{array}$ & $\begin{array}{l}\text { vehicle } \\
\text { vehicle }\end{array}$ & $\begin{array}{l}\mathrm{E}_{2}(5 \mu \mathrm{g}) \\
\text { vehicle }\end{array}$ & $\begin{array}{l}\text { DPN }(10 \mu \mathrm{g}) \\
\text { vehicle }\end{array}$ & $\begin{array}{l}\text { PPT }(50 \mu \mathrm{g}) \\
\text { vehicle }\end{array}$ & $\begin{array}{l}\text { PPT } \\
\text { sertraline }\end{array}$ & $\begin{array}{l}\text { vehicle } \\
\text { sertraline }\end{array}$ & $\begin{array}{l}\text { G1 }(10 \mu \mathrm{g}) \\
\text { vehicle }\end{array}$ \\
\hline
\end{tabular}

this study examined the behavioral consequences of longer-term treatments with $\mathrm{E}_{2}$ or ER subtype-selective agonists and/or an SSRI in the forced swim test (FST). A second part of this study investigated whether behavioral effects of long-term $E_{2}$ are associated with changes in the signaling pathways and/or modulatory receptors (TrkB) in the hippocampus accompanying ER activation and/or SSRI-induced AD-like effects. As stated above, the signaling pathways (MAPK/ERK1/2 and PI3K/Akt) and TrkB receptor, selected in this study, are involved not only in signaling through ERs but also are prominently involved in many effects produced by ADs.

\section{Methods}

\section{Animals}

Ovariectomized (OVX) rats (Sprague-Dawley; 250-280 g, 4 months old, Harlan, Indianapolis, Ind., USA) were housed on a 12:12-hour light/dark cycle with lights on at 07:00 and with food and water provided ad libitum. All animal procedures were in accordance with the National Institutes of Health Guide for the Care and Use of Laboratory Animals and were approved by the local Institutional Animal Care and Use Committee. All efforts were made to minimize the number of animals used or stress and discomfort to the animals during the experimental procedure. OVX rats were allowed 2-3 weeks' recovery after surgery before the start of the experiment.

\section{Drug Treatment}

For the FST experiments, in experiment 1, OVX rats were administered for 2 weeks the following compounds subcutaneously via implantation of one osmotic minipump containing either $E_{2}$
( $5 \mu \mathrm{g} /$ day, Sigma-Aldrich, St. Louis, Mo., USA), the ER $\beta$ agonist DPN ( 5 or $10 \mu \mathrm{g} /$ day, Bio-Techne, Minneapolis, Minn., USA), the GPR30 agonist G1 (5-100 $\mu \mathrm{g} /$ day, Bio-Techne) or the SSRI sertraline $(10 \mathrm{mg} / \mathrm{kg} /$ day $)$. For experiment 2 , examining the effect of the ER $\alpha$ agonist PPT (Bio-Techne) on the AD-like effect of sertraline, two osmotic minipumps were subcutaneously implanted into rats. One was filled with either PPT or vehicle and the other with sertraline or vehicle as shown in table 1 . The control group received vehicle which consisted of $25 \% \mathrm{EtOH} / \mathrm{H}_{2} \mathrm{O}$. In these experiments, 6-14 rats were used in each group.

For the Western blot analysis experiments, OVX rats were implanted with two osmotic minipumps subcutaneously for 2 weeks. The treatments are as shown in table 2. In these experiments, 6 rats were used in each group.

The dose of $E_{2}$ used in this study was shown to produce serum $\mathrm{E}_{2}$ levels seen in proestrus [34]. The initial doses used for ER agonists selected are based on that same study. However, when no effect was obtained with a low dose, higher doses were also tried to make sure that the lack of effect was not due to a dose that was too low. Control groups received vehicle which consisted of $25 \%$ $\mathrm{EtOH} / \mathrm{H}_{2} \mathrm{O}$.

The behavioral experiments shown in figures 1 and 2 consisted of 2 cohorts. In the first cohort a lower dose of $E_{2}$ and ER agonists was used. In the second cohort a higher dose of the agonists was used when necessary. Each cohort had its own control group ( $\mathrm{n}=$ 7). The results, with low and high doses were combined in the same figures and the two separate control groups were also to provide a larger number of 14. The dose of sertraline was selected as it was shown not only to downregulate the SERT but also to produce an AD-like effect in the FST when given chronically [35-37].

The efficacy of the treatment paradigms were confirmed by body and uterine weight. It has been shown that ERa mediates the attenuating effect of $\mathrm{E}_{2}$ on body weight gain as well as that of increased uterine weight after $\mathrm{E}_{2}$ treatment [38-44]. Changes in 


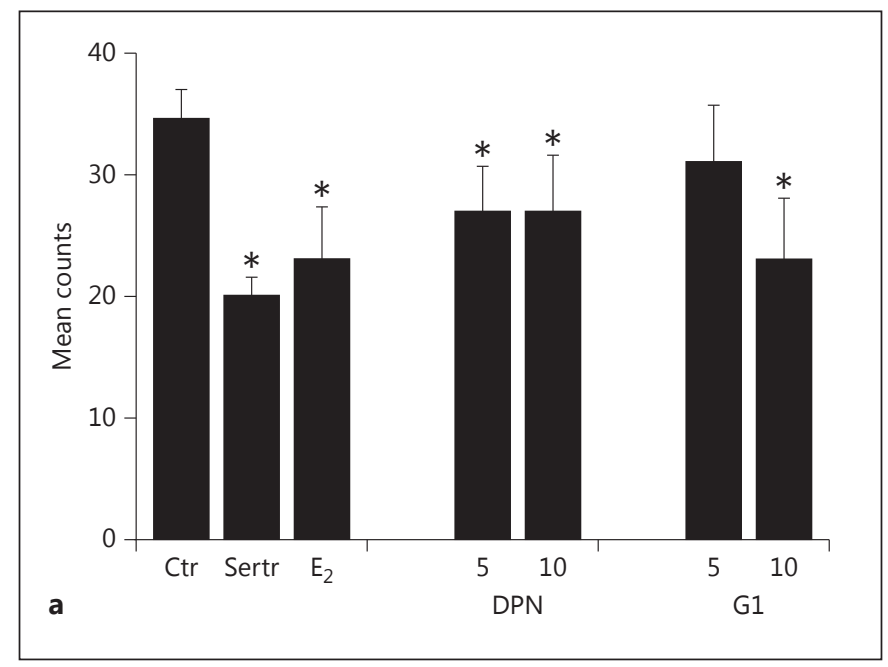

Fig. 1. Effect of long-term treatment with $\mathrm{E}_{2}, \mathrm{ER} \beta, \mathrm{GPR} 30$ agonists and sertraline (Sertr) in the FST. OVX rats were treated for 2 weeks with $\mathrm{E}_{2}, \mathrm{DPN}, \mathrm{G} 1$ or sertraline via subcutaneous osmotic minipumps, as described in the Methods section. Mean counts for immobility, swimming and climbing behaviors were sampled every $5 \mathrm{~s}$ of the swim test period. Bars and brackets represent the mean value $\pm S D, n=6-14 /$ group. None of the treatment groups had al-

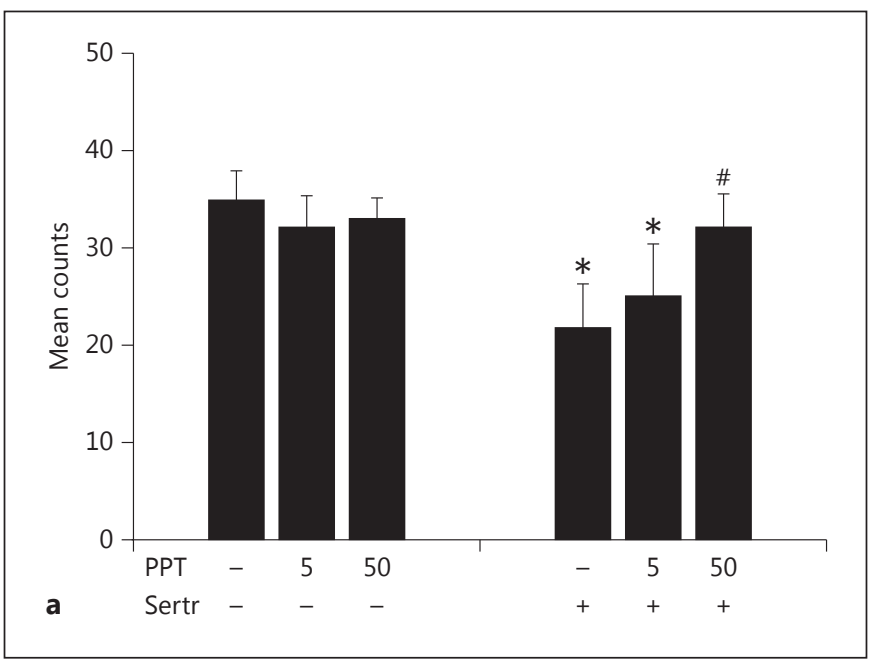

Fig. 2. Effect of long-term treatment with an ERa agonist (PPT) alone or combined with an SSRI in the FST. OVX rats were treated for 2 weeks with PPT and/or sertraline (Sertr) via subcutaneous osmotic minipumps, as described in the Methods section. Mean counts for immobility, swimming and climbing behaviors were sampled every $5 \mathrm{~s}$ of the swim test period. Bars and brackets represent the mean value $\pm \mathrm{SD}, \mathrm{n}=6-14$ /group. None of the treatment groups had altered climbing behavior (data not shown). a Immobility: two-way ANOVA showed a significant main effect for sertraline $\left(\mathrm{F}_{1,54}=33.56, \mathrm{p}<0.001\right)$ and for PPT $\left(\mathrm{F}_{3,54}=4.58, \mathrm{p}<0.006\right)$

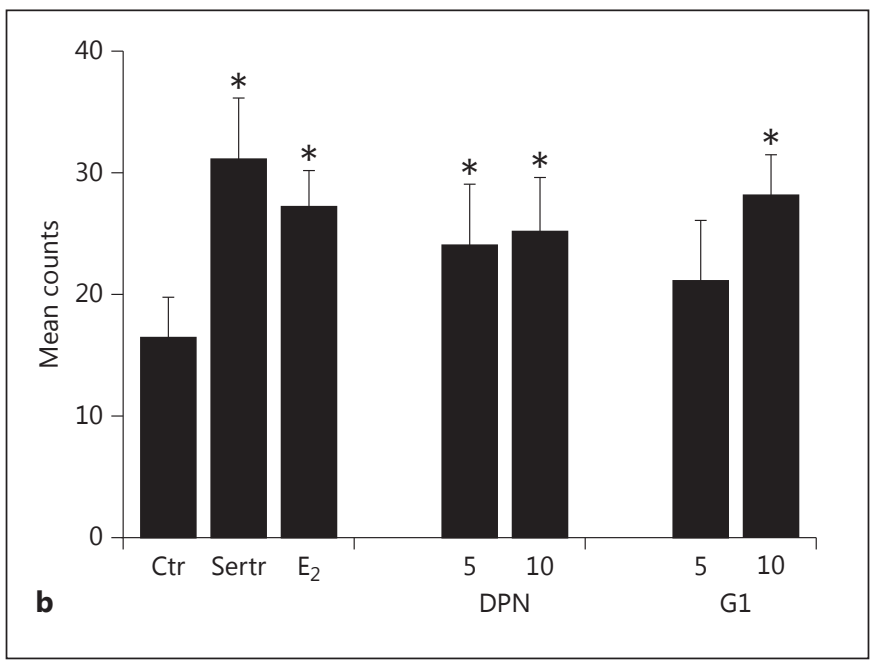

tered climbing behavior (data not shown). a Immobility: one-way ANOVA revealed that there was a significant main effect between groups $\left(\mathrm{F}_{6,48}=17.11, \mathrm{p}<0.001\right)$. b Swimming: one-way ANOVA revealed that there was a significant main effect between groups $\left(\mathrm{F}_{6,48}=14.26, \mathrm{p}<0.001\right)$. a, b Dunnett's post hoc analysis was carried out; ${ }^{*} \mathrm{p}<0.001$, comparing all groups with the control (Ctr) group.

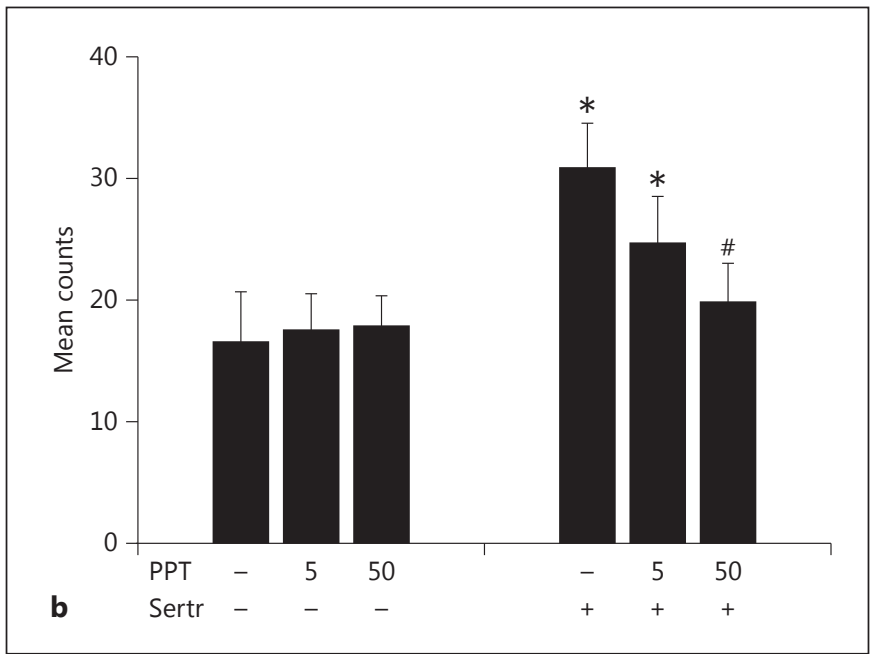

as well as a significant interaction between sertraline $\times$ PPT $\left(\mathrm{F}_{3,54}=10.32, \mathrm{p}<0.001\right)$. b Swimming: two-way ANOVA showed a significant main effect for sertraline $\left(\mathrm{F}_{1,54}=44.52, \mathrm{p}<0.001\right)$ and for PPT $\left(\mathrm{F}_{3,54}=6.43, \mathrm{p}<0.001\right)$ as well as a significant interaction between sertraline $\times \operatorname{PPT}\left(\mathrm{F}_{3,54}=12.80, \mathrm{p}<0.001\right)$. $\mathbf{a}, \mathbf{b}$ Dunnett's post hoc analysis was carried out; ${ }^{*} \mathrm{p}<0.001$, comparing each treatment group with the control group (vehicle/vehicle); ${ }^{\#} \mathrm{p}<$ 0.001 , comparing PPT ( 5 or $50 \mu \mathrm{g}$ )/sertraline groups with vehicle/ sertraline group. 
body weight after different treatment were measured (the weight of rats at the end of the treatment was subtracted from their weight just before the start of treatment). In addition, at the end of a longterm treatment with $\mathrm{E}_{2}$ or ER agonists, the uteri were collected and weighed immediately after removal.

\section{Forced Swim Test}

A modified FST procedure from the one described by Cryan et al. [45] was used. On day 15 of chronic treatment (while hormones and/or SSRIs were still administered), a swim test session of $5 \mathrm{~min}$ was carried out with no pretest session. This approach is used in order to avoid the extended delay ( 2 weeks) between the first (pretest) and the second exposure (test) or the impact of hormone being present during the pretest session if pretest and test are separated by the usual $24 \mathrm{~h}$. In addition, it has been shown that positive results with the drugs could be obtained even if no training session was carried out. Rats were placed individually into a Plexiglas cylinder $(21 \times 46 \mathrm{~cm})$ filled with $25^{\circ} \mathrm{C}$ water to a depth of $35 \mathrm{~cm}$ for a 5-min swim, and behaviors were recorded by a video camera positioned above the tank. A time sampling technique was employed whereby the predominant behavior in each 5 -second bin of the test was analyzed. Climbing was defined as upward-directed movements of the forepaws along the side of the swim chamber. Swimming was defined as active movements (usually horizontal) throughout the swim chamber, which also include crossing into another quadrant. Immobility is assigned when there was no active movement other than that necessary to keep the rat's head above the water. The rater was blind with respect to the experimental conditions being scored.

\section{Western Blot Analysis}

To prevent changes in the phosphorylation level of proteins due to stress from the FST experiment, another set of rats was used for these experiments. OVX rats were treated as described above. After completion of drug treatment (14 days), the hippocampus was dissected and homogenized in lysis buffer containing $50 \mathrm{mM}$ Tris- $\mathrm{HCl}, 1 \mathrm{~mm}$ EDTA, $0.35 \%$ sodium deoxycholate, $150 \mathrm{~mm}$ $\mathrm{NaCl}, 1 \%$ Igepal, phosphatase inhibitors and protease inhibitors. After incubation on ice for $30 \mathrm{~min}$, samples were centrifuged for $15 \mathrm{~min}$ at $13,000 \mathrm{~g}$. Protein levels of the collected supernates were determined using the Bradford assay. Each sample was run on SDS-PAGE gel and blotted onto a nitrocellulose membrane. The blot was incubated overnight at $4^{\circ} \mathrm{C}$ with the following primary antibodies: anti-phospho-Y515 (1:1,000; Abcam, Cambridge, Mass., USA), anti-phospho-Y705 (1:1,000; Abcam), anti-phospho-Y816 (1:4,000; Abcam) and anti-TrkB (1:10,000; Neuromics, Edina, Minn., USA), anti-phospho-Akt (S473, 1:1,000; Cell Signaling Technology, Danvers, Mass., USA), anti-phospho-Akt (T308, 1:1,000; Cell Signaling Technology) and anti-Akt (1:1,000; Cell Signaling Technology), anti-phospho-ERK1/2 (1:1,000; Cell Signaling Technology) and anti-ERK1/2 (1:1,000; Cell Signaling Technology). Equal loading was confirmed using anti- $\beta$-actin (1:200,000, Sigma-Aldrich) and used for normalization. After three washes, the membranes are incubated with the appropriate horseradish peroxidase-conjugated secondary antibody $(1: 20,000$, Sigma-Aldrich) for $1 \mathrm{~h}$ at room temperature. Enhanced chemiluminescence detection is used followed by an exposure to X-ray film for enhanced chemiluminescence detection. Relative densities were measured using the NIH imageJ program. Phosphoprotein values are normalized and calculated as a ratio against total protein

Antidepressant Effects of $\mathrm{E}_{2}$ and ER

Agonists
Table 3. Uterine weight after 14 days' treatment with vehicle, $\mathrm{E}_{2}$ or ER agonists

Uterine weight, mg

\begin{tabular}{lc}
\hline Vehicle $(\mathrm{n}=14)$ & $103 \pm 4.7$ \\
$\mathrm{E}_{2}(5 \mu \mathrm{g})(\mathrm{n}=7)$ & $418 \pm 12.7^{*}$ \\
DPN $(5 \mu \mathrm{g})(\mathrm{n}=7)$ & $98 \pm 1.6$ \\
DPN $(10 \mu \mathrm{g})(\mathrm{n}=6)$ & $104 \pm 4.4$ \\
G1 $(5 \mu \mathrm{g})(\mathrm{n}=7)$ & $103 \pm 5.2$ \\
G1 $(10 \mu \mathrm{g})(\mathrm{n}=7)$ & $108 \pm 2.2$ \\
PPT $(5 \mu \mathrm{g})(\mathrm{n}=7)$ & $350 \pm 10.3^{*}$ \\
PPT $(50 \mu \mathrm{g})(\mathrm{n}=7)$ & $508 \pm 14.9^{*}$
\end{tabular}

Values represent means $\pm \mathrm{SD}$. OVX rats were treated for 2 weeks with drugs via osmotic minipumps, as described in the Methods section. At the end of treatment/experiment, the uterine horn was dissected and weighed. One-way ANOVA showed a significant main effect $\left(\mathrm{F}_{7,53}=3,339.38, \mathrm{p}<0.001\right)$. Dunnett's post hoc analysis was carried out; ${ }^{*} \mathrm{p}<0.001$, comparing all groups with the vehicle group.

values. The results are shown graphically as a percentage of the control group.

\section{Statistical Analysis}

Data were analyzed using SigmaStats (Systat Software Inc., San Jose, Calif., USA). One-way analysis of variance (ANOVA) followed by Dunnett's analysis was used when comparisons were made with the control group (tables 3, 4, 6; fig. 1). Two-way ANOVA followed by Dunnett's analysis was used to compare (1) the effect of PPT within the vehicle and within the sertraline groups and (2) the effect of sertraline within the vehicle and within the PPT groups (table 5; fig. 2). For all the Western blot analyses, where the data are expressed as percentage of control, the Kruskal-Wallis test followed by Dunnett's post hoc analysis was used to compare all groups with vehicle and the sertraline group with the PPT + sertraline group (fig. 3-6). Only when there was a significant main effect and/or interaction effect in the ANOVA were post hoc analyses carried out. Significance was determined at $\mathrm{p}<0.05$.

\section{Results}

\section{Long-Term Effects of Treatment with $E_{2}$ and ER}

Agonists on Uterine Weight

Uterine weights were investigated as a peripheral marker of estrogenic activity. As expected, treatment with $\mathrm{E}_{2}$ and PPT ( 5 as well as $50 \mu \mathrm{g}$ ) increased uterine weight significantly as compared to the weights in vehicle-treated rats. By contrast, treatment with either DPN or G1 (each at 5 or $10 \mu \mathrm{g}$ ) did not have any effect (table 3 ). 
Fig. 3. Effect of long-term treatment with $\mathrm{E}_{2}$, DPN, PPT and/or sertraline (Sertr) on phosphorylation levels of Akt (T308) in the hippocampus. OVX rats were treated for 2 weeks with drugs via osmotic minipumps, as described in the Methods section. Western blot analysis of hippocampal levels of total Akt and that of phospho-Akt (T308) were carried out. Representative Western blotting of phospho-Akt and total Akt is shown in the upper inserted panel. A single band was detected at approximatively 60 $\mathrm{kDa}$ that corresponds to phospho-Akt or total Akt. Bars represent mean value \pm SD of phospho- to total protein ratio $(n=6)$. Kruskal-Wallis test showed a significant main effect $\left(\mathrm{F}_{5,30}=7.52, \mathrm{p}<0.001\right)$. Dunnett's post hoc was carried out; ${ }^{*} \mathrm{p}<0.01$, comparing all groups with the control (Ctr) group.

Fig. 4. Effect of long-term treatment with $\mathrm{E}_{2}, \mathrm{DPN}, \mathrm{PPT}$ and/or sertraline (Sertr) on phosphorylation levels of ERK2 (Y204) in the hippocampus. OVX rats were treated for 2 weeks with drugs via osmotic minipumps, as described in the Methods section. Western blot analysis of hippocampal levels of total ERK and that of phosphoERK (Y204) were carried out. Representative Western blotting of phospho- ERK1/2 and total ERK1/2 is shown in the upper inserted panel. Bands of phospho-p42 and phospho-p44, ERK-like immunoreactivity at approximately 42 and $44 \mathrm{kDa}$, respectively, were detected. Only data from phospho-ERK2 are quantified; pERK1 was not quantified due to poor immunoreactivity. Bars represent mean value \pm SD of phospho- to total protein ratio $(n=6)$. KruskalWallis test showed a statistically significant difference among the treatment groups $(\mathrm{p}=0.005)$. Dunnett's post hoc analysis was carried out; ${ }^{*} \mathrm{p}<0.05$, comparing all groups with the control (Ctr) group.
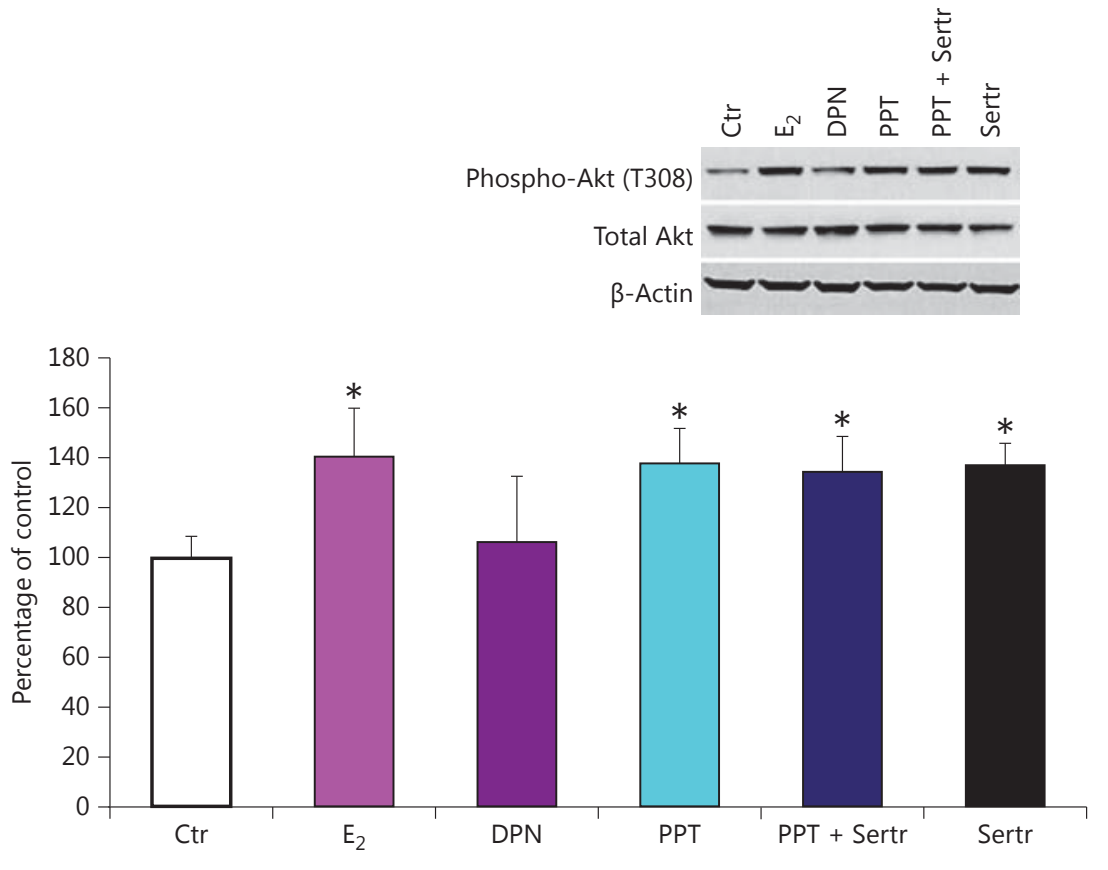

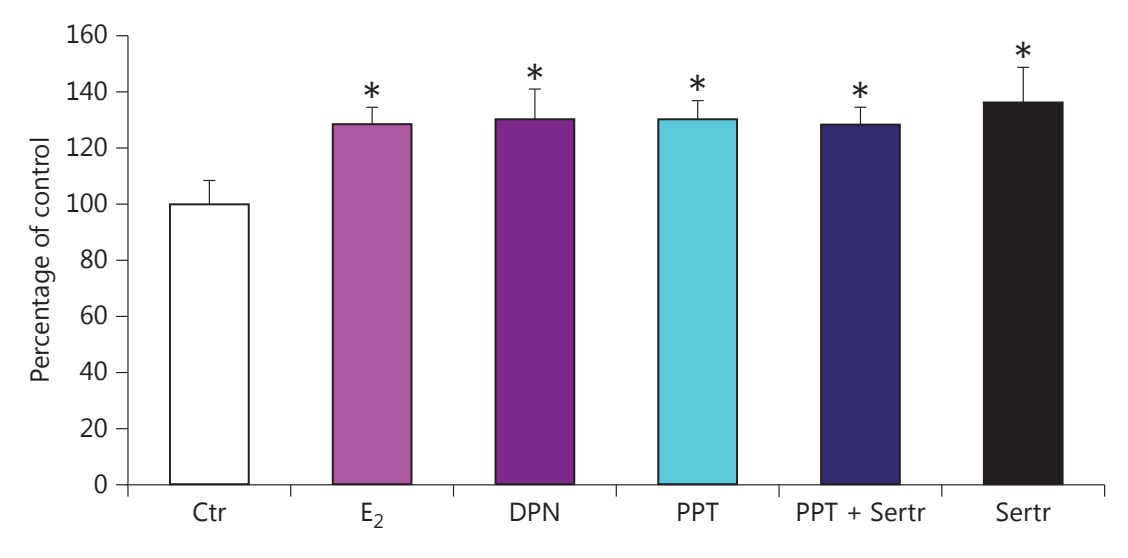


Fig. 5. Effect of long-term treatment with $\mathrm{E}_{2}$, DPN, PPT and/or sertraline (Sertr) on phosphorylation levels of TrkB (Y705) in the hippocampus. OVX rats were treated for 2 weeks with drugs via osmotic minipumps, as described in the Methods section. Western blot analysis of hippocampal levels of total TrkB and that of phosphoTrkB (Y705) were carried out. Representative Western blotting of Y705 and total TrkB is shown in the upper inserted panel. A single band was detected at approximatively $92 \mathrm{kDa}$ that corresponds to Y705 or total TrkB. Bars represent mean value \pm SD of the phospho- to total protein ratio $(\mathrm{n}=$ 6). Kruskal-Wallis test showed a significant main effect $\left(\mathrm{F}_{5,30}=18.61, \mathrm{p}<0.001\right)$. Dunnett's post hoc analysis was carried out; $* \mathrm{p}<0.001$, comparing all groups with the control (Ctr) group; ${ }^{*} \mathrm{p}<0.001$, comparing the sertraline group with the PPT + sertraline group.

Fig. 6. Effect of long-term treatment with $\mathrm{E}_{2}$, DPN, PPT and/or sertraline (Sertr) on phosphorylation levels of TrkB (Y816) in the hippocampus. OVX rats were treated for 2 weeks with drugs via osmotic minipumps, as described in the Methods section. Western blot analysis of hippocampal levels of total TrkB and that of phosphoTrkB (Y816) were carried out. Representative Western blotting of Y816 and total TrkB is shown in the upper inserted panel. A single band was detected at approximatively $92 \mathrm{kDa}$ that corresponds to Y816 or total TrkB. Bars represent mean value \pm SD of phosphoprotein to total protein ratio $(\mathrm{n}=6)$. Kruskal-Wallis test showed a significant main effect $\left(\mathrm{F}_{5,30}=14.07, \mathrm{p}<\right.$ $0.001)$. Dunnett's post hoc analysis was carried out; ${ }^{*} \mathrm{p}<0.001$, comparing all groups with the control (Ctr) group; ${ }^{\#} \mathrm{p}<0.05$, comparing the sertraline group with the $\mathrm{PPT}+$ sertraline group.
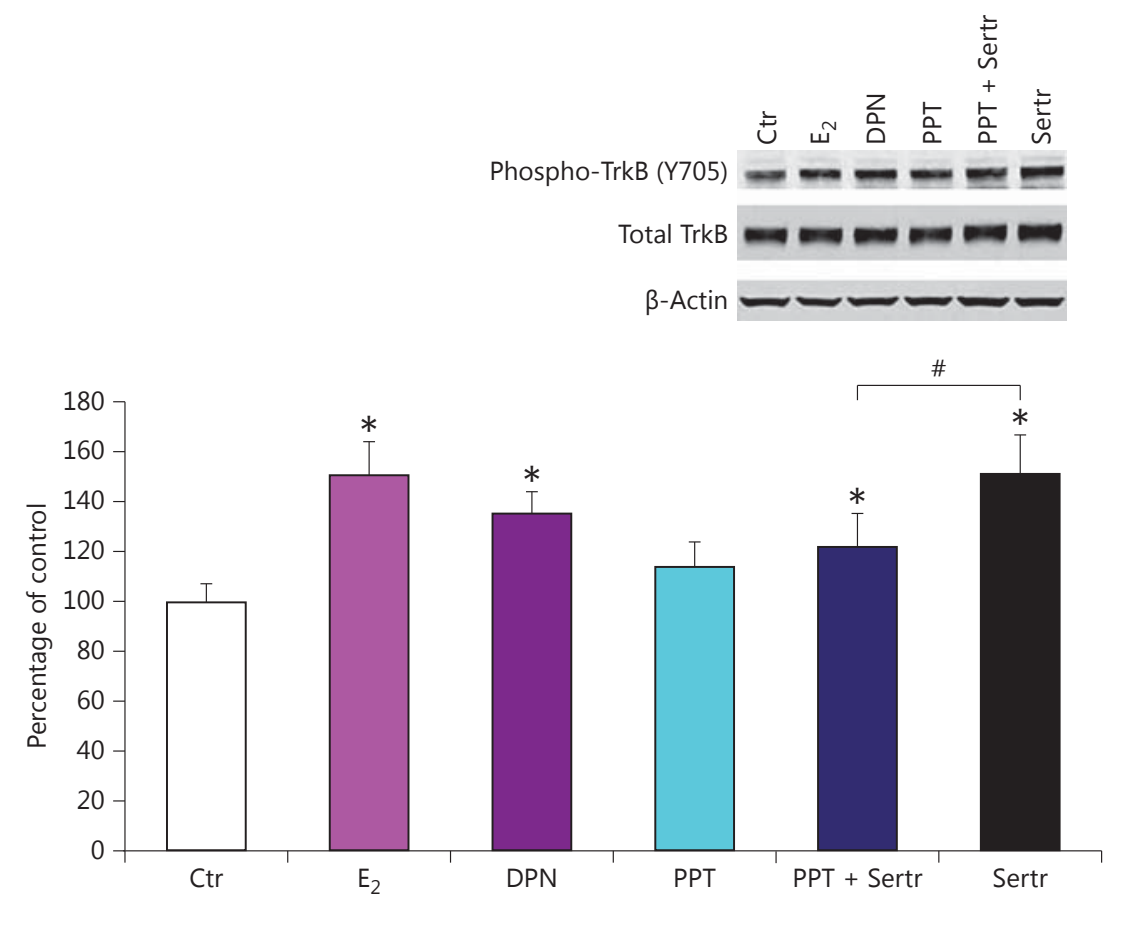

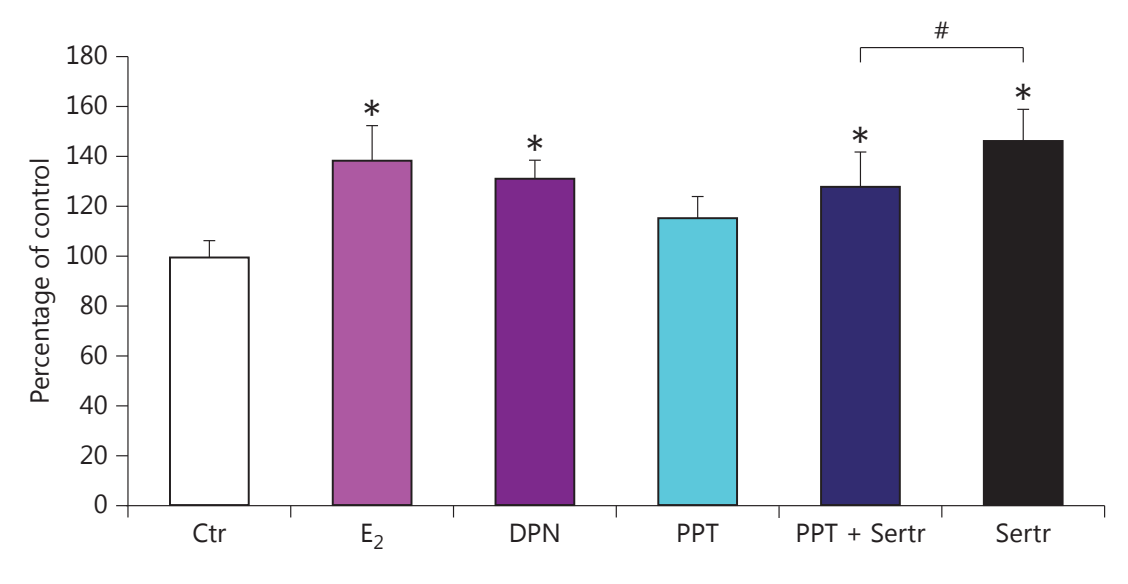


Table 4. Change in body weight after 14 days' treatment with vehicle, sertraline, $\mathrm{E}_{2}$, ERa or GPR30 agonists

\section{Change in body weight, $g$}

\begin{tabular}{lc}
\hline Vehicle $(\mathrm{n}=14)$ & $+36 \pm 7.5$ \\
Sertraline $(\mathrm{n}=7)$ & $+31 \pm 9.2$ \\
$\mathrm{E}_{2}(5 \mu \mathrm{g})(\mathrm{n}=7)$ & $-1 \pm 15.0^{*}$ \\
DPN $(5 \mu \mathrm{g})(\mathrm{n}=7)$ & $+29 \pm 6.4$ \\
DPN $(10 \mu \mathrm{g})(\mathrm{n}=6)$ & $+41 \pm 9.6$ \\
G1 $(5 \mu \mathrm{g})(\mathrm{n}=7)$ & $+29 \pm 9.0$ \\
G1 $(10 \mu \mathrm{g})(\mathrm{n}=7)$ & $+38 \pm 4.5$ \\
\hline
\end{tabular}

Values represent a mean change in body weight \pm SD after chronic treatment with drugs: the weight of the rat at the end of the treatment was subtracted from the weight of the rat at the beginning of the treatment. One-way ANOVA was carried out. There was a significant main effect between groups $\left(\mathrm{F}_{6,48}=17.04\right.$, $\mathrm{p}<0.001)$. Dunnett's post hoc analysis was carried out; ${ }^{*} \mathrm{p}<0.001$, comparing all groups with the vehicle group.

Table 5. Change in body weight after 14 days' treatment with the $\mathrm{ER} \alpha$ agonist $\mathrm{PPT}$ and/or sertraline

\begin{tabular}{lc}
\hline & Change in body weight, $\mathrm{g}$ \\
\hline Vehicle/vehicle $(\mathrm{n}=11)$ & $+45 \pm 6.7$ \\
PPT $(5 \mu \mathrm{g}) /$ vehicle $(\mathrm{n}=7)$ & $+37 \pm 5.9$ \\
PPT $(50 \mu \mathrm{g}) /$ vehicle $(\mathrm{n}=6)$ & $-1 \pm 4.9^{*}$ \\
Vehicle/sertraline $(\mathrm{n}=11)$ & $+40 \pm 10.8$ \\
PPT $(5 \mu \mathrm{g}) /$ sertraline $(\mathrm{n}=7)$ & $+40 \pm 10.4$ \\
PPT $(50 \mu \mathrm{g}) /$ sertraline $(\mathrm{n}=7)$ & $+33 \pm 8.3^{\#}$
\end{tabular}

Values represent a mean change in body weight \pm SD after chronic treatment with drugs: the weight of the rat at the end of the treatment was subtracted from the weight of the rat at the beginning of the treatment. Two-way ANOVA was carried out for weight change in the sertraline and PPT groups. There was a significant main effect for sertraline $\left(\mathrm{F}_{1,43}=18.27, \mathrm{p}<0.001\right)$ and for $\operatorname{PPT}\left(\mathrm{F}_{2,43}=42.76, \mathrm{p}<0.001\right)$ as well as a significant interaction between SSRI $\times$ PPT $\left(\mathrm{F}_{2,43}=22.46, \mathrm{p}<0.001\right)$. Dunnett's post hoc analysis was carried out; ${ }^{*} \mathrm{p}<0.001$, comparing PPT within the vehicle and within sertraline groups; ${ }^{*} \mathrm{p}<0.001$, comparing sertraline within the vehicle and within the PPT groups.

\section{Long-Term Effects of Treatment with $E_{2}$, ER Agonists} and/or Sertraline on the Change in Body Weight

The initial body weights of the various groups before treatments were not significantly different (data not shown). Tables 4 and 5 show the changes in body weight produced by the various treatments. After 2 weeks of treatment with vehicle, there was a 36 - to 45 -gram gain in body weight. Long-term treatment with an ER $\beta$ or a GPR30 agonist also resulted in a weight gain that was not statistically different from that obtained after treatment with vehicle. However, treatment with $\mathrm{E}_{2}$ resulted in a small weight loss $(-1 \mathrm{~g})$ that was statistically different from the weight gain obtained after treatment with vehicle (table 4). Long-term treatment with sertraline also induced a similar increase in body weight (31-40 g) as that measured in control rats (tables 4, 5). Long-term treatment with the ER $\alpha$ agonist PPT had a dose-dependent effect on body weight. At a low dose $(5 \mu \mathrm{g})$, weight gain was equivalent to that obtained in control rats. However, at a higher dose $(50 \mu \mathrm{g})$, PPT treatment decreased the body weight significantly compared to the body weight gain seen in vehicle rats. It is interesting to note that in the presence of sertraline the effect of the higher dose of PPT on body weight was not observed (table 5).

Long-Term Effects of $E_{2}$, ER Agonists and/or Sertraline in the FST

The behavioral consequences of longer-term treatment with $\mathrm{E}_{2}$ or ER subtype-specific agonists and/or sertraline were examined in the FST. As expected, chronic treatment with sertraline induced $\mathrm{AD}$-like behavior in the FST, i.e., decreased immobility and increased swimming behavior as compared to that in control rats. Similarly, AD-like effects were found after chronic treatment with $\mathrm{E}_{2}$, DPN ( 5 or $10 \mu \mathrm{g}$ ) or G1 (at 10 but not at $5 \mu \mathrm{g}$ ) (fig. 1). Increasing doses of DPN (from 5 to $10 \mu \mathrm{g}$ ) or G1 (from 10 to $100 \mu \mathrm{g}$ ) did not produce greater behavioral effects (data not shown for G1 above $10 \mu \mathrm{g}$ ). None of the treatments altered climbing behavior (data not shown).

Chronic treatment with the ERa agonist PPT at doses up to $100 \mu \mathrm{g}$ had no effect on immobility or swimming behaviors compared to those measured in control rats. However, the decreased immobility and increased swimming behaviors induced by chronic treatment with sertraline were blocked by long-term treatment with PPT (at either 50 or $100 \mu \mathrm{g})$. PPT at $5 \mu \mathrm{g}$ did not alter the sertraline-induced decreased immobility but significantly lowered the sertraline-induced increased swimming behavior in the FST (fig. 2). Again, none of the treatments altered climbing behavior (data not shown).

Long-Term Effects of $E_{2}$, ER Agonists and/or Sertraline on Phosphorylation Levels of TrkB and Signaling

Proteins

Activation of signaling proteins was assessed by increases in their phosphorylation status in the hippocampus after long-term (14 days) treatment with $\mathrm{E}_{2}$, ER ago- 
Table 6. Effect of long-term treatment with G1 (10 $\mu \mathrm{g} /$ day, 2 weeks) on the phosphorylation levels of Akt, ERK and TrkB in the hippocampus of OVX rats

\begin{tabular}{lccl}
\hline Groups & pAkt (T308) & pERK2 (Y204) & pTrkB (Y816) \\
\hline Control $(\mathrm{n}=6)$ & $99.6 \pm 13$ & $99.5 \pm 9$ & $100.4 \pm 22$ \\
G1 $(\mathrm{n}=6)$ & $134.0 \pm 15^{*}$ & $141.2 \pm 15^{*}$ & $159.8 \pm 17^{*}$ \\
\hline
\end{tabular}

Values represent means of a percentage of the control group \pm SD. OVX rats were treated for 2 weeks with G1 or vehicle (control group) via osmotic minipumps, as described in the Methods section. Western blot analysis of hippocampal levels of total protein and that of phosphoprotein for Akt, ERK and TrkB (Y816) were carried out. Phosphoprotein values are normalized and calculated as a ratio against total protein values. Total protein levels for Akt, ERK and TrkB were not altered by G1 treatment when compared to values in the vehicle treatment group (data not shown). One-way ANOVA followed by Dunnett's post hoc analysis was carried out; ${ }^{*} \mathrm{p}<0.05$, comparing each group with its control group.

nists and/or sertraline, using Western blot analysis. Total protein levels for Akt, ERK and TrkB were not altered by any of the treatments when compared to values in the vehicle treatment group (fig. 3-6). Akt was examined at two phosphorylation sites threonine (T) 308 and serine (S) 473. Phospho-Akt (T308) was significantly increased after treatment with $\mathrm{E}_{2}, \mathrm{G} 1, \mathrm{PPT}$, sertraline and the combination of PPT with sertraline; however, treatment with DPN did not alter the phosphorylation level of Akt as compared to control values (fig. 3; table 6). Similar results were obtained with phospho-Akt at S473 (data not shown). Phospho-ERK2 (at tyrosine (Y) 204) was significantly increased in all treatment groups as compared to the values in the control group (fig. 4; table 6). Western blot analysis of TrkB phosphorylation revealed that phosphorylation levels at tyrosine 705 were increased after long-term treatment with $\mathrm{E}_{2}$, DPN and sertraline alone or when the SSRI was combined with PPT. While long-term treatment with PPT alone did not alter phosphorylation at Y705 as compared to that seen in the control group, it is interesting to note that the combination of sertraline and PPT produced an increase in Y705 that was significantly smaller than that obtained after sertraline alone (fig. 5). A similar pattern of results were obtained at Y816 on $\operatorname{TrkB}$ as treatment with $\mathrm{E}_{2}, \mathrm{DPN}, \mathrm{G} 1$ and sertraline alone or sertraline and PPT increased the phosphorylation levels at tyrosine 816 , whereas treatment with PPT alone did not have any effect as compared to that seen in the control group (fig. 6; table 6). Again, the combination of sertraline and PPT produced an increase in Y816 that was significantly smaller than that obtained after sertraline alone. There were no changes in TrkB phosphorylation at Y515 (data not shown).

\section{Discussion}

These results demonstrate that long-term treatment of young adult OVX rats with $\mathrm{E}_{2^{-}}, \mathrm{ER} \beta$ - or GPR30-selective agonists induced an AD-like behavior in the FST, i.e., decreased immobility and increased swimming behavior. This effect is similar to that obtained after chronic treatment with the SSRI sertraline. Long-term treatment with the ER $\alpha$ agonist (PPT) had no effect of its own in the FST; however, it blocked the AD-like effect of sertraline. Furthermore, long-term treatment with $\mathrm{E}_{2}$, GPR30 agonist or sertraline increased the phosphorylation levels of signaling proteins such as Akt, ERK and that of the TrkB receptor in the hippocampus. Long-term treatment with ER subtype-selective agonists induced similar changes in the levels of phosphorylation of signaling proteins as those obtained with $\mathrm{E}_{2}$ except that treatment with DPN did not alter phospho-Akt, whereas PPT did not change TrkB phosphorylation levels.

The lack of a gain in body weight associated with increased uterine weight after long-term treatment with $\mathrm{E}_{2}$ validates the efficacy of the dose of $E_{2}$ used (tables 3,4 ). ER subtype-selective agonists had different effects on body and uterine weight (tables 3-5). PPT both increased uterine weight and at a dose of $50 \mu \mathrm{g}$ maintained body weight at a level similar to $\mathrm{E}_{2}$ consistent with the idea that ERa plays a predominant role in uterine proliferation and maintenance of body weight $[38,43,46,47]$. DPN and G1 did not alter uterine weight, which is in agreement with previous reports $[39,48]$. Weight gain also increased with these agonists to an extent similar to that seen in the vehicle-treated rats.

The AD-like effects of $\mathrm{E}_{2}$ mediated via ER $\beta$ have been shown in rodents in several studies, using subtype-selective agonists as well as knockout $(\mathrm{KO})$ animals. In acute studies, administration of $\mathrm{E}_{2}$ or ER $\beta$-selective ER modulators (SERMs) systemically or directly into the hippocampus decreased anxiety and depressive behavior whereas administration of ERa-specific SERMs did not $[9,49]$. Similarly, the AD-like effect of $E_{2}$ or DPN in the FST was shown in mice and this effect was lost in ER $\beta$ $\mathrm{KO}$ mice [7]. Long-term treatment of OVX rats with $\mathrm{E}_{2}$ or DPN induced an AD-like effect in the FST whereas treatment with PPT had no effect $[50,51]$. Consistent 
with these data, the results obtained in this study indicate that $E_{2}, D P N$ as well as $G 1$ have an AD-like effect in the FST after long-term treatment. Most importantly, PPT by itself had no effect in the FST, but it blocked the ADlike effect of sertraline (fig. 1, 2). Even though the lower dose of PPT increased uterine weight, PPT at this dose had no effect on the AD-like effect of sertraline (table 4; fig. 2). It is possible that this low dose was not physiologically effective since it was not associated with a lack of body weight gain as was the case for the higher dose (50 $\mu \mathrm{g})$.

The long-term treatment data from the FST are consistent with the results obtained previously using chronoamperometry to measure the rate of clearance of $5-\mathrm{HT}$ from the $\mathrm{CA}_{3}$ region of the hippocampus $[10,13]$. In these studies, the $\mathrm{AD}$-like effect of $\mathrm{E}_{2}$ (i.e., slower 5-HT clearance) was due to ER $\beta$ and/or GPR30 activation as their specific agonists mimicked the effect of $\mathrm{E}_{2}$. By contrast, the blockade of $E_{2}$ of the ability of SSRI fluvoxamine to slow 5-HT clearance was mimicked only by an ERa agonist [10].

The regulation of the serotonergic system by $E_{2}$ leading to the behavioral responses is mediated by ER subtypes that can be located in 5-HT neurons and/or non-5HT neurons. In general, it is thought that ER $\beta$ but not $\mathrm{ER} \alpha$ is present in 5-HT neurons. However, the patterns for the expression of the two ER subtypes in 5-HT neurons in the dorsal raphe nucleus (DRN) are species dependent as well as controversial. In rats, it was shown that 5 -HT neurons of the DRN contain mRNA for ER $\beta$ but not ERa [52]. Distinct groups of 5-HT-immunoreactive neurons in the DRN were found to show $\mathrm{ER} \alpha$ and/or ER $\beta$ expression in mice but not in rats [53]. In mice, $\operatorname{ER} \beta$, but not ERa, was found located within 5-HT neurons [54, 55]. In nonhuman primates, $\mathrm{ER} \beta$, but not $\mathrm{ER} \alpha$, seems to be the predominant ER expressed in raphe 5-HT neurons [56-58]. Although GPR30 immunoreactivity was found throughout the brain, it is however not known whether GPR30 is localized in 5-HT neurons [59, 60]. Local activation of ER $\beta$ by either $E_{2}$ or DPN in the DRN increased the expression of tryptophan hydroxylase-2 (TPH2), the brain-specific rate-limiting enzyme for 5-HT synthesis, and decreased despair-like behavior in the FST; however, it failed to decrease anxiety-like behavior [61]. That study demonstrated that $\mathrm{E}_{2}$ 's regulation of despair-like behavior may primarily involve ER $\beta$ located in the DRN whereas its effect in regulating anxiety-like behavior could involve ER located in other brain areas such as the hypothalamus or the amygdala. Further studies will be necessary to investigate whether the ERs mediating the effect of $\mathrm{E}_{2}$ on serotonergic function obtained in the present study are located on 5-HT and/or non-5-HT neurons.

Although we have concentrated our effort on the effect of $E_{2}$ in the hippocampus, it is important to note that effects of $E_{2}$ occur throughout the brain. In addition to the hippocampus, affective behaviors are also modulated by other limbic structures including the amygdala. This brain region contains a high amount of ERs [62]. The amygdala is well known as a brain region important for modulating fear and anxiety behavior $[63,64]$ and has also been investigated for its importance for affective behavior through a kindling model [65]. The importance of the amygdala for the sex-specific or hormone-dependent modulation of neurobiological changes underlying anxiety disorders has been demonstrated in several studies. For example, lesions of the central nucleus of the amygdala lead to decreased anxiety-type behaviors and decreased neuroendocrine responses to a spectrum of stressors $[66,67]$. Systemic as well as intra-amygdala $\mathrm{E}_{2}$ administration increased antianxiety behavior in OVX rats [49].

There is an interplay between ERs, certain signaling cascades and the TrkB receptor in the behavioral effects of $E_{2}$. Activation of dorsal hippocampal PI3K/Akt and ERK signaling pathways is necessary for $\mathrm{E}_{2}$ to enhance object recognition memory in young as well as middleaged female mice $[68,69]$. Similarly, the activation of $\mathrm{ER} \alpha, \mathrm{ER} \beta$ or GPR30 results in an induction of ERK-Akt signaling pathways mediating neuroprotection and preservation of cognitive function [70,71]. Both MAPK and $\mathrm{PI} 3 \mathrm{~K}$ are required in the neuronal actions of estrogen in facilitating female reproductive behavior as lordosis induced by $E_{2}$ in rats was abolished in the presence of specific inhibitors of the two signaling pathways [72]. In addition to the importance of these two signaling pathways in the effects of $E_{2}$, the activation of the TrkB receptor plays a critical role in $\mathrm{E}_{2}$-induced neuroprotection from NMDA toxicity [73]. Furthermore, evidence for the TrkB receptor as a mediator of the effects of $E_{2}$ in the hippocampus has been demonstrated [18].

In this study, long-term treatment with $\mathrm{E}_{2}$ increased phosphorylation levels of Akt, ERK and TrkB in the hippocampus, and these effects were similar to those observed after chronic treatment with sertraline (fig. 3-6). Long-term treatment with a GPR30 agonist produced effects similar to those of $E_{2}$ (table 6). Interestingly, longterm treatment with ER $\alpha$ and ER $\beta$ agonists produced a different pattern of results such that Akt phosphorylation was not changed after DPN treatment whereas PPT treatment did not alter TrkB phosphorylation (fig. 3, 5, 6). 
PPT, unlike DPN, did not display an AD-like effect in the FST (fig. 1, 2). Taken together, one might hypothesize that $\operatorname{TrkB}$ activation is necessary for an $\mathrm{AD}$-like effect to occur in response to SSRIs, $\mathrm{E}_{2}$, and ER $\beta$ - and GPR30-selective agonists. By contrast, activation of Akt may not be required for the DPN-induced $\mathrm{AD}$-like effect in the FST, and perhaps that of $E_{2}$ and $\mathrm{G} 1$ as well. Recently published findings from acute studies strengthen this hypothesis. Using selective inhibitors of signaling pathways or those of interacting receptors showed that the acute $\mathrm{E}_{2}$-induced slowing of 5-HT clearance via activation of ER $\beta$ required MAPK/ERK1/2 signaling pathways and involved interactions with the TrkB receptor. However, the $\mathrm{E}_{2}$-induced prevention of the ability of an SSRI to slow 5-HT clearance, via activation of ER $\alpha$, required MAPK/ERK1/2 and $\mathrm{PI} 3 \mathrm{~K} / \mathrm{Akt}$ signaling pathways but not TrkB receptor activation [19]. Perhaps consistent with this idea is also that long-term treatment with the combination of PPT and sertraline significantly reduced the level of phosphorylation of TrkB as compared to sertraline alone (fig. 5, 6), and it also blocked the AD-like effect of sertraline (fig. 2). However, further studies using inhibitors of signaling pathways or those of interacting receptors may offer a better perspective on the impact of signaling pathways and the TrkB receptor in the behavioral effects observed after long term-treatment with $\mathrm{E}_{2^{-}}$or ER-selective agonists. Nonetheless, these data provide insight into the intracellular activation of specific signaling proteins that accompany these treatments and that could be involved in the $\mathrm{AD}$-like behavioral responses obtained with $\mathrm{E}_{2}$.

In addition to its interaction with estrogen, $\mathrm{BDNF} /$ TrkB is also involved in the mechanism(s) of action of ADs [27] and perhaps the pathogenesis of depression [74]. Evidence that activation of the TrkB receptor is required for a behavioral response typically induced by ADs has been shown [27]. Numerous studies have also implicated MAPK and PI3K pathways in the etiology and treatment of mood disorders. Pharmacological manipulations of these signaling pathways also affect behavior in models of depression and AD response [24, 26, 75]. These pathways have become major pharmacological targets for putative neuropsychiatric treatments. Our results strengthen the idea that $\mathrm{E}_{2}$ activation of $\mathrm{ER} \alpha, \mathrm{ER} \beta$ or GPR30 leads to behavioral effects that could be due at least in part to activation of ERK, Akt and/or the TrkB receptor in the hippocampus. Such information could be useful in identifying novel drug targets that would bypass ERs.

In conclusion, $\mathrm{E}_{2}$ has both an $\mathrm{AD}$-like effect as well as an effect that interferes with the efficacy of SSRIs. Different ERs and differences in ER-coupled signaling pathways produce these two different effects of $\mathrm{E}_{2}$. Understanding the way in which estrogens affect the SERT function in young adult animals is a first step to defining age-related changes in response to hormones. Whether $\mathrm{E}_{2}$ has effects in a rodent model of peri- or postmenopausal depression similar to effects seen in younger adult rats is under investigation. And if so, then ER $\beta$-selective agonists, or novel drugs that would target their signaling pathways, are likely to be more efficacious in postmenopausal depressed patients than $\mathrm{E}_{2}$.

\section{Acknowledgements}

This research was supported by funds from NARSAD, the Department of Veterans Affairs and the National Institute of Mental Health (MH090386).

\section{Disclosure Statement}

Dr. S. Benmansour, Mr. O.S. Adeniji and Mr. A.A. Privratsky have no biomedical financial interests or potential conflicts of interest. Dr. A. Frazer has been on advisory boards for Cyberonics, Inc., H. Lundbeck A/S and Takeda Pharmaceuticals America, Inc. and he has consulted and/or received research support for preclinical studies from Forest Research Institute, Eli Lilly and Company, Wyeth Pharmaceuticals and H. Lundbeck A/S. No support for this study was received from any pharmaceutical company.

\section{References}

$>1$ Green S, Walter P, Greene G, Krust A, Goffin C, Jensen E, Scrace G, Waterfield M, Chambon $\mathrm{P}$ : Cloning of the human oestrogen receptor cDNA. J Steroid Biochem 1986;24:77-83.

-2 Kuiper GG, Enmark E, Pelto-Huikko M, Nilsson S, Gustafsson JA: Cloning of a novel receptor expressed in rat prostate and ovary. Proc Natl Acad Sci USA 1996;93:5925-5930.
>3 Zhao C, Dahlman-Wright K, Gustafsson JA: Estrogen receptor beta: an overview and update. Nucl Recept Signal 2008;6:e003.

4 Shughrue PJ, Lane MV, Merchenthaler I: Comparative distribution of estrogen receptor-alpha and -beta mRNA in the rat central nervous system. J Comp Neurol 1997;388: 507-525. $\checkmark 5$ Krezel W, Dupont S, Krust A, Chambon P, Chapman PF: Increased anxiety and synaptic plasticity in estrogen receptor beta-deficient mice. Proc Natl Acad Sci USA 2001;98: 12278-12282.

6 Imwalle DB, Gustafsson JA, Rissman EF: Lack of functional estrogen receptor beta influences anxiety behavior and serotonin content in female mice. Physiol Behav 2005;84:157-163.
Antidepressant Effects of $\mathrm{E}_{2}$ and $\mathrm{ER}$

Agonists
Neuroendocrinology 2016;103:269-281 DOI: $10.1159 / 000437268$ 
7 Rocha BA, Fleischer R, Schaeffer JM, Rohrer SP, Hickey GJ: 17 Beta-estradiol-induced antidepressant-like effect in the forced swim test is absent in estrogen receptor-beta knockout (BERKO) mice. Psychopharmacology (Berl) 2005;179:637-643.

8 Walf AA, Frye CA: Administration of estrogen receptor beta-specific selective estrogen receptor modulators to the hippocampus decrease anxiety and depressive behavior of ovariectomized rats. Pharmacol Biochem Behav 2007;86:407-414.

$\checkmark 9$ Walf AA, Ciriza I, Garcia-Segura LM, Frye CA: Antisense oligodeoxynucleotides for estrogen receptor-beta and alpha attenuate estradiol's modulation of affective and sexual behavior, respectively. Neuropsychopharmacology 2008;33:431-440.

10 Benmansour S, Weaver RS, Barton AK, Adeniji OS, Frazer A: Comparison of the effects of estradiol and progesterone on serotonergic function. Biol Psychiatry 2012;71:633-641.

$\checkmark 11$ Katzenellenbogen BS: Mechanisms of action and cross-talk between estrogen receptor and progesterone receptor pathways. J Soc Gynecol Investig 2000;7:S33-S37.

$\checkmark 12$ Levin ER: Rapid signaling by steroid receptors. Am J Physiol Regul Integr Comp Physiol 2008;295:R1425-R1430.

13 Benmansour S, Piotrowski JP, Altamirano AV, Frazer A: Impact of ovarian hormones on the modulation of the serotonin transporter by fluvoxamine. Neuropsychopharmacology 2009;34:555-564.

14 Prossnitz ER, Oprea TI, Sklar LA, Arterburn JB: The ins and outs of gpr30: a transmembrane estrogen receptor. J Steroid Biochem Mol Biol 2008;109:350-353.

15 Filardo EJ, Thomas P: Minireview: G proteincoupled estrogen receptor-1, GPER-1: its mechanism of action and role in female reproductive cancer, renal and vascular physiology. Endocrinology 2012;153:2953-2962.

16 Quesada A, Etgen AM: Functional interactions between estrogen and insulin-like growth factor-I in the regulation of alpha $1 \mathrm{~b}$ adrenoceptors and female reproductive function. J Neurosci 2002;22:2401-2408.

17 Micevych P, Dominguez R: Membrane estradiol signaling in the brain. Front Neuroendocrinol 2009;30:315-327.

-18 Spencer-Segal JL, Tsuda MC, Mattei L, Waters EM, Romeo RD, Milner TA, McEwen BS, Ogawa S: Estradiol acts via estrogen receptors alpha and beta on pathways important for synaptic plasticity in the mouse hippocampal formation. Neuroscience 2012;202:131-146.

19 Benmansour S, Privratsky AA, Adeniji OS, Frazer A: Signaling mechanisms involved in the acute effects of estradiol on 5-HT clearance. Int J Neuropsychopharmacol 2014;17:765-777.

20 Scharfman HE, Maclusky NJ: Similarities between actions of estrogen and BDNF in the hippocampus: coincidence or clue? Trends Neurosci 2005;28:79-85.

-21 Spencer JL, Waters EM, Romeo RD, Wood GE, Milner TA, McEwen BS: Uncovering the mechanisms of estrogen effects on hippocampal function. Front Neuroendocrinol 2008; 29:219-237.

22 Bockaert J, Perroy J, Becamel C, Marin P, Fagni L: GPCR interacting proteins (GIPs) in the nervous system: roles in physiology and pathologies. Annu Rev Pharmacol Toxicol 2010; 50:89-109.

23 Schloss P, Williams DC: The serotonin transporter: a primary target for antidepressant drugs. J Psychopharmacol 1998;12:115-121.

24 Polter AM, Li X: Glycogen synthase kinase-3 is an intermediate modulator of serotonin neurotransmission. Front Mol Neurosci 2011;4:31.

25 Artigas F: Serotonin receptors involved in antidepressant effects. Pharmacol Ther 2013; 137:119-131.

26 Tanis KQ, Duman RS: Intracellular signaling pathways pave roads to recovery for mood disorders. Ann Med 2007;39:531-544.

27 Schmidt HD, Duman RS: The role of neurotrophic factors in adult hippocampal neurogenesis, antidepressant treatments and animal models of depressive-like behavior. Behav Pharmacol 2007;18:391-418.

28 Huang EJ, Reichardt LF: Neurotrophins: roles in neuronal development and function. Annu Rev Neurosci 2001;24:677-736.

-29 Saarelainen T, Hendolin P, Lucas G, Koponen E, Sairanen M, MacDonald E, Agerman K, Haapasalo A, Nawa H, Aloyz R, Ernfors P, Castren E: Activation of the TrkB neurotrophin receptor is induced by antidepressant drugs and is required for antidepressant-induced behavioral effects. J Neurosci 2003;23: 349-357.

-30 Rantamaki T, Hendolin P, Kankaanpaa A, Mijatovic J, Piepponen P, Domenici E, Chao MV, Mannisto PT, Castren E: Pharmacologically diverse antidepressants rapidly activate brain-derived neurotrophic factor receptor TrkB and induce phospholipase-Cgamma signaling pathways in mouse brain. Neuropsychopharmacology 2007;32:2152-2162.

31 Furmaga H, Carreno FR, Frazer A: Vagal nerve stimulation rapidly activates brain-derived neurotrophic factor receptor TrkB in rat brain. PLoS One 2012;7:e34844.

- 32 Kornstein SG, Toups M, Rush AJ, Wisniewski SR, Thase ME, Luther J, Warden D, Fava M, Trivedi MH: Do menopausal status and use of hormone therapy affect antidepressant treatment response? Findings from the sequenced treatment alternatives to relieve depression $\left(\mathrm{STAR}^{*} \mathrm{D}\right)$ study. J Womens Health (Larchmt) 2013;22:121-131.

33 Soares CN: Mood disorders in midlife women: understanding the critical window and its clinical implications. Menopause 2014;21: 198-206.

-34 Hammond R, Mauk R, Ninaci D, Nelson D, Gibbs RB: Chronic treatment with estrogen receptor agonists restores acquisition of a spatial learning task in young ovariectomized rats. Horm Behav 2009;56:309-314.

35 Benmansour S, Cecchi M, Morilak DA, Gerhardt GA, Javors MA, Gould GG, Frazer A:
Effects of chronic antidepressant treatments on serotonin transporter function, density, and mRNA level. J Neurosci 1999;19:1049410501.

36 Bilge S, Bozkurt A, Bas DB, Aksoz E, Savli E, Ilkaya F, Kesim Y: Chronic treatment with fluoxetine and sertraline prevents forced swimming test-induced hypercontractility of rat detrusor muscle. Pharmacol Rep 2008;60: 872-879.

37 Furmaga H, Shah A, Frazer A: Serotonergic and noradrenergic pathways are required for the anxiolytic-like and antidepressant-like behavioral effects of repeated vagal nerve stimulation in rats. Biol Psychiatry 2011;70: 937-945.

38 Harris HA, Katzenellenbogen JA, Katzenellenbogen BS: Characterization of the biological roles of the estrogen receptors, ERalpha and ERbeta, in estrogen target tissues in vivo through the use of an ERalpha-selective ligand. Endocrinology 2002;143:4172-4177.

39 Le Saux M, Di Paolo T: Influence of oestrogenic compounds on monoamine transporters in rat striatum. J Neuroendocrinol 2006; 18:25-32.

40 Lund TD, Rovis T, Chung WC, Handa RJ: Novel actions of estrogen receptor-beta on anxiety-related behaviors. Endocrinology 2005;146:797-807.

41 Roesch DM: Effects of selective estrogen receptor agonists on food intake and body weight gain in rats. Physiol Behav 2006;87: 39-44.

42 Santollo J, Wiley MD, Eckel LA: Acute activation of ER alpha decreases food intake, meal size, and body weight in ovariectomized rats. Am J Physiol Regul Integr Comp Physiol 2007;293:R2194-R2201.

43 Wegorzewska IN, Walters K, Weiser MJ, Cruthirds DF, Ewell E, Larco DO, Handa RJ, $\mathrm{Wu} \mathrm{TJ}$ : Postovariectomy weight gain in female rats is reversed by estrogen receptor alpha agonist, propylpyrazoletriol. Am J Obstet Gynecol 2008;199:67.e61-e65.

44 Neese SL, Korol DL, Katzenellenbogen JA, Schantz SL: Impact of estrogen receptor alpha and beta agonists on delayed alternation in middle-aged rats. Horm Behav 2010;58:878890.

45 Cryan JF, Page ME, Lucki I: Differential behavioral effects of the antidepressants reboxetine, fluoxetine, and moclobemide in a modified forced swim test following chronic treatment. Psychopharmacology (Berl) 2005;182: 335-344.

46 Lubbers LS, Zafian PT, Gautreaux C, Gordon M, Alves SE, Correa L, Lorrain DS, Hickey GJ, Luine V: Estrogen receptor (ER) subtype agonists alter monoamine levels in the female rat brain. J Steroid Biochem Mol Biol 2010;122: 310-317.

47 Lowry NC, Pardon LP, Yates MA, Juraska JM: Effects of long-term treatment with 17 betaestradiol and medroxyprogesterone acetate on water maze performance in middle aged female rats. Horm Behav 2010;58:200-207. 
-48 Windahl SH, Andersson N, Chagin AS, Martensson UE, Carlsten H, Olde B, Swanson C, Moverare-Skrtic S, Savendahl L, Lagerquist MK, Leeb-Lundberg LM, Ohlsson C: The role of the G protein-coupled receptor GPR30 in the effects of estrogen in ovariectomized mice. Am J Physiol Endocrinol Metab 2009; 296:E490-E496.

-49 Walf AA, Rhodes ME, Frye CA: Antidepressant effects of ERbeta-selective estrogen receptor modulators in the forced swim test. Pharmacol Biochem Behav 2004;78:523-529.

50 Weiser MJ, Wu TJ, Handa RJ: Estrogen receptor-beta agonist diarylpropionitrile: biological activities of R- and S-enantiomers on behavior and hormonal response to stress. Endocrinology 2009;150:1817-1825.

-51 Yang F, Tao J, Xu L, Zhao N, Chen J, Chen W, Zhu Y, Qiu J: Estradiol decreases rat depressive behavior by estrogen receptor beta but not alpha: no correlation with plasma corticosterone. Neuroreport 2014;25:100-104.

- $52 \mathrm{Lu} \mathrm{H}$, Ozawa H, Nishi M, Ito T, Kawata M: Serotonergic neurones in the dorsal raphe nucleus that project into the medial preoptic area contain oestrogen receptor beta. J Neuroendocrinol 2001;13:839-845.

53 Compton DR, Sheng S, Carlson KE, Rebacz NA, Lee IY, Katzenellenbogen BS, Katzenellenbogen JA: Pyrazolo[1,5-a]pyrimidines: estrogen receptor ligands possessing estrogen receptor beta antagonist activity. J Med Chem 2004;47:5872-5893.

54 Nomura M, Akama KT, Alves SE, Korach KS, Gustafsson JA, Pfaff DW, Ogawa S: Differential distribution of estrogen receptor (ER)-alpha and ER-beta in the midbrain raphe nuclei and periaqueductal gray in male mouse: predominant role of ER-beta in midbrain serotonergic systems. Neuroscience 2005;130:445456.

55 Suzuki H, Barros RP, Sugiyama N, Krishnan V, Yaden BC, Kim HJ, Warner M, Gustafsson JA: Involvement of estrogen receptor beta in maintenance of serotonergic neurons of the dorsal raphe. Mol Psychiatry 2013;18:674680.

56 Gundlah C, Kohama SG, Mirkes SJ, Garyfallou VT, Urbanski HF, Bethea CL: Distribution of estrogen receptor beta (ERbeta) mRNA in hypothalamus, midbrain and tem- poral lobe of spayed macaque: continued expression with hormone replacement. Brain Res Mol Brain Res 2000;76:191-204.

57 Gundlah C, Lu NZ, Mirkes SJ, Bethea CL: Estrogen receptor beta (ERbeta) mRNA and protein in serotonin neurons of macaques. Brain Res Mol Brain Res 2001;91:14-22.

58 Vanderhorst VG, Terasawa E, Ralston HJ 3rd: Estrogen receptor-alpha immunoreactive neurons in the brainstem and spinal cord of the female rhesus monkey: species-specific characteristics. Neuroscience 2009;158:798810.

59 Brailoiu E, Dun SL, Brailoiu GC, Mizuo K, Sklar LA, Oprea TI, Prossnitz ER, Dun NJ: Distribution and characterization of estrogen receptor $\mathrm{G}$ protein-coupled receptor 30 in the rat central nervous system. J Endocrinol 2007; 193:311-321.

60 Matsuda K, Sakamoto H, Mori H, Hosokawa K, Kawamura A, Itose M, Nishi M, Prossnitz ER, Kawata M: Expression and intracellular distribution of the $G$ protein-coupled receptor 30 in rat hippocampal formation. Neurosci Lett 2008;441:94-99.

61 Donner N, Handa RJ: Estrogen receptor beta regulates the expression of tryptophan-hydroxylase 2 mRNA within serotonergic neurons of the rat dorsal raphe nuclei. Neuroscience 2009;163:705-718.

62 Shughrue PJ, Merchenthaler I: Distribution of estrogen receptor beta immunoreactivity in the rat central nervous system. J Comp Neurol 2001;436:64-81.

63 LeDoux JE: Emotion circuits in the brain. Annu Rev Neurosci 2000;23:155-184.

64 Walf AA, Sumida K, Frye CA: Inhibiting 5alpha-reductase in the amygdala attenuates antianxiety and antidepressive behavior of naturally receptive and hormone-primed ovariectomized rats. Psychopharmacology (Berl) 2006;186:302-311.

65 Adamec R, Shallow T: Rodent anxiety and kindling of the central amygdala and nucleus basalis. Physiol Behav 2000;70:177-187.

66 Beaulieu S, Di Paolo T, Barden N: Control of ACTH secretion by the central nucleus of the amygdala: implication of the serotoninergic system and its relevance to the glucocorticoid delayed negative feedback mechanism. Neuroendocrinology 1986;44:247-254.
67 Feldman S, Conforti N, Itzik A, Weidenfeld J: Differential effect of amygdaloid lesions on CRF-41, ACTH and corticosterone responses following neural stimuli. Brain Res 1994;658: 21-26.

68 Fernandez SM, Lewis MC, Pechenino AS, Harburger LL, Orr PT, Gresack JE, Schafe GE, Frick KM: Estradiol-induced enhancement of object memory consolidation involves hippocampal extracellular signal-regulated kinase activation and membrane-bound estrogen receptors. J Neurosci 2008;28:8660-8667.

69 Fan L, Zhao Z, Orr PT, Chambers CH, Lewis MC, Frick KM: Estradiol-induced object memory consolidation in middle-aged female mice requires dorsal hippocampal extracellular signal-regulated kinase and phosphatidylinositol 3-kinase activation. J Neurosci 2010;30:4390-4400.

70 Yang LC, Zhang QG, Zhou CF, Yang F, Zhang YD, Wang RM, Brann DW: Extranuclear estrogen receptors mediate the neuroprotective effects of estrogen in the rat hippocampus. PLoS One 2010;5:e9851.

71 Lamar M, Craig M, Daly EM, Cutter WJ, Tang C, Brammer M, Rubia K, Murphy DG: Acute tryptophan depletion promotes an anteriorto-posterior fMRI activation shift during task switching in older adults. Hum Brain Mapp 2014;35:712-722.

72 Etgen AM, Acosta-Martinez M: Participation of growth factor signal transduction pathways in estradiol facilitation of female reproductive behavior. Endocrinology 2003;144:3828-3835.

73 Aguirre CC, Baudry M: Progesterone reverses 17beta-estradiol-mediated neuroprotection and BDNF induction in cultured hippocampal slices. Eur J Neurosci 2009;29:447-454.

74 Kaufman J, Yang BZ, Douglas-Palumberi H, Grasso D, Lipschitz D, Houshyar S, Krystal JH, Gelernter J: Brain-derived neurotrophic factor-5-HTTLPR gene interactions and environmental modifiers of depression in children. Biol Psychiatry 2006;59:673-680.

75 Chen YC, Tan QR, Dang W, Wang HN, Zhang RB, Li ZY, Lin H, Liu R: The effect of citalopram on chronic stress-induced depressive-like behavior in rats through GSK3beta/beta-catenin activation in the medial prefrontal cortex. Brain Res Bull 2012;88: 338-344.
Antidepressant Effects of $\mathrm{E}_{2}$ and $\mathrm{ER}$ Agonists
Neuroendocrinology 2016;103:269-281 